\title{
Assessment of Sex Offender Notification Policy in the United States: Has the Policy Been Working?
}

\author{
Jisun Choi $^{1,2} \&$ Mijin Kim $^{1,2}$ \\ ${ }^{1}$ John Jay College of Criminal Justice, The City University of New York, New York, USA \\ ${ }^{2}$ Graduate Center, The City University of New York, New York, USA \\ Correspondence: Jisun Choi, John Jay College of Criminal Justice, New York, USA
}

Received: November 20, 2015

Accepted: December 2, $2015 \quad$ Available online: December 17, 2015

doi:10.11114/ijsss.v4i1.1206

URL: http://dx.doi.org/10.11114/ijsss.v4i1.1206

\begin{abstract}
The National Sex Offender Registration and Notification (SORN) policies in the United States have been one of the major policies against sex offense since 2006. In this paper, we attempt to assess the policies within a framework of four types of failure in criminal justice reform by Berman and Fox - Theory, Marketing and Politics, Implication, and Self-Reflection. According to the evaluation, the SORN policies have not been successful, fitting into the four failures. Even though the policies were successfully initiated by the public and politics, the lack of theoretical framework led the whole process of the policies into the failure. In addition, the implication of the policies has been challenging because of constitutional and ethical concerns of the offenders. Although a sufficient amount of literature has presented the ineffectiveness of the policies, more applications are attempted by policymakers. Before deeper and wider problems occur, the criminal justice system must be more reasonable on the subject. For future policy reform, we recommend that policymakers consider the previous studies and start thinking about a sound framework for the policies.
\end{abstract}

Keywords: National Sex Offender Registration and Notification (SORN), policy assessment, sex offender policy

\section{Introduction}

Policies against sex offenses in the United States have drastically evolved since the early 1990s with occurrences of high-profile sex offense cases, such as those involving Jacob Wetterling and Megan Kanka. Since then, two significant changes have been made with sex offender policies and these changes, creating the Sex Offender Registration and Notification policy (SORN). In 1994, the federal government enacted the Sex Offender Registration policy as part of the Jacob Wetterling Act. Thus, the states built sex offender registries containing the offenders' official records that had been created by the police. Two years later, in 1996, as a part of Megan's Law, the states started to notify the public of the information about sex offenders in their neighborhood - the start of Sex Offender Notification policy. In 2006, the Sex Offender Registration and Notification Act (SORNA) was officially enacted by the United States Congress under title I of the Adam Walsh Child Protection and Safety Act of 2006. Accordingly, National Guideline for Sex Offender Registration and Notification was published in 2008. While policies are getting tougher on sex offenders, the sex offender registries are becoming more accessible to the general public with the development of technology.

It has been almost 10 years since the policies were introduced in the United States. Over the past decade, researchers have discussed various aspects of these policies, such as legal concerns and effectiveness of the policies. In this report, we will review the recent studies regarding the policies to evaluate whether the Sex Offender Registration and Notification policies have been effective as it originally intended to achieve. In order to examine the policies thoroughly, we applied four concepts of assessing the policy - Theory, Marketing, Implementation, and Self-Reflection - from the book Trial \& Error in Criminal Justice: Learning from Failure by Berman and Fox. Moreover, we discuss potential directions for future sex offender policy reform.

\section{Four Types of Failures in Criminal Justice Reform}

In the field of criminal justice, a great deal of attention is paid to identifying evidence-based programs to meet specific goals for crime prevention. However, there is no doubt that the process of establishing certain criminal justice policy is painstaking, and certain crime prevention programs experience programmatic failures. As stated in the book Trial \& Error Criminal Justice Reform: Learning from Failure, Berman and Fox suggest that such a policy failure is not due to 
incompetent practitioners; rather, because change is very difficult to achieve. They argue that "failure is usually the product of a complicated chemistry involving a specific time, a specific place, and specific personalities" (Berman \& Fox, 2011, p. 1). They mainly propose four general types of failures in criminal justice reform. First, failure of concept or simply a "bad idea" in reform can cause a serious downfall. In criminal justice reforms, in general, the policies are intended to protect the citizens from crimes and criminals. However, without understanding well thought-out theories and ideas related to the current circumstances, reform can be a reckless movement. One example of this failure type is the "three-strike law," which mandates punitive sentences to habitual offenders. The idea of the initiative is to prevent repeated offenders who attribute significantly to the overall crime rate by increasing the severity of the criminal sanction. Even though the initial idea is out of 'goodwill,' the concept 'three strikes,' the frequency of offenses had no base whatsoever. Ultimately, the reforms have heavily failed in California, causing prison overcrowding problems (Zimring, 1996). California's "three strikes, you are out" law under the 1994 Violent Crime Control and Law Enforcement Act and its broad definition of "third strike" put many minor offenders behind the bars. For instance, in a highly publicized case of Jerry DeWayne Williams, Jerry was sentenced to prison for mandatory 25 years to life for stealing a slice of pepperoni pizza (Stolzenberg \& D'Alessio, 1997). As a result of unintended consequences of three strikes law, state prisons held a hundred and twenty-three people for each hundred thousand U.S. residents in 1978; by 2007, that figure had risen to four hundred and sixty-one.

The second type of failure is related to marketing and politics. In spite of the construction of highly promising plans and reforms, the reform itself becomes a failure if the public and politics have no or little desire to ratify. Regarding marketing reforms, some policies had been implemented without specific plans and resources for supplying sufficient funding and man-power. These issues can be considered as a double-edged sword, which means that there will be a failure either with too little attention (failure to market effectively) or with too much attention. Oftentimes, criminal justice reforms are publically enforced due to high-profile crimes, such as terrorism and sex offenses. Excessive attention to reforms can be challenging mainly because the process of reform must be immediate.

Third, a policy reform can fail when it is poorly executed even though the reform is well-planned out with a very sound idea and sufficient resources. Poor execution of any policy causes total failure. In particular, the criminal justice system is highly vulnerable to this aspect. The criminal justice system has a unique characteristic that involves relatively large numbers of people for the same goal. For instance, when an individual commits a crime, the police officers, specialized investigators (e.g., Crime Scene Investigators), prosecutors, judicial officials, correctional personnel, and sometimes victims and related families are involved in one process in the criminal justice system. One poor execution at any level of the system can cause the failure.

Finally, reformers will face a failure if accurate evaluations are not conducted. Moreover, the results of evaluations must be interpreted properly to improve the reform. "Scared Straight" programs are one of the examples that stands out as an evident policy failure due to lack of strong theoretical basis. Although "Scared Straight" programs are used throughout the nation as a means of deterring juvenile delinquency, they have been proven ineffective in meeting its goal; rather, they have been ineffective by resulting in an increase of the likelihood of future delinquency by an average of $17 \%$ (Lipsey, 1992). Despite these unintended consequences, several states, such as New York and Florida, still use Scared Straight programs as a juvenile crime prevention strategy. This implies that it is significant for reformers to assess their own weaknesses and respond to a change in short-time basis.

Above all, aforementioned four types of common failures (i.e., building concept, marketing, and politics, poor execution, evaluation) in criminal justice reform are what reformers must avoid in the aims of successful policy reform. We argue that certain policies that are free from those types of failures can be an ultimate success. In sum, these four types are seen as four steps toward successful reform; from conceptualizing a good idea, to convincing politicians and the public effectively, to gaining a sufficient amount of resources, and to properly implementing the reform by evaluating the process and effectiveness of improvements. By borrowing this framework, the current study evaluates the Sex Offender Registration and Notification policies (SORN) in the United States.

\section{Sex Offender Registration and Notification Policy in America}

The public has a visceral reaction to sex offenders because many violent acts committed by sex offenders are serious crimes that involve even young children. As a consequence, sex offenders and sexual offenses actually provoke public fear (reaction) that makes legislators and policymakers to come up with regulations that are not observed with any other types of convicted offenders. Highly publicized cases such as Wetterling and Kanka cases in 1994 and 1996, respectively, were the main triggers for SORN implementation. Yet, it is important to understand the dynamics of success or the outcomes of the law (or SORNA). Therefore, in the following section, we examine implemented steps of the SORN policies by using Berman and Fox's four types of failures of criminal justice policy: Marketing and Politics, Theory and Concept, Implementation, and Self-Reflection. 


\subsection{Marketing and Politics}

Two major sex-offense cases of 11-year-old Jacob Wetterling and 7-year-old Megan Kanka enraged the public enough to push the politicians to 'do something' about the incidents. The fact that children were the victims of the heinous sexual abuse created the peculiar circumstances of almost full support from the public to the politicians creating punitive punishment for child sex offenders. The Sex Offender Registration and Notification policies were just part of being tough on sex offenders - punitive sentences and chemical castration policies. Because of the public consensus and willingness of the politicians, a marketing process for the successful policy reform was not necessary. Furthermore, although the policies required some resources such as manpower for dealing with the registry data, building the sex offender registry open to the public was not very expensive since the registries already existed as the police records, compared to other criminal justice policies such as incarceration. Given these notions, it appears that marketing process of SORN was successful. However, it was not due to a smart strategy or well-thought-out idea. At that point in time, the public was already eager to buy any policy that was harsh on child sex offenders.

According to a study by Meloy, Saleh, and Wolff (2007), the sex offender registration and community notification were 'panic-driven legislations' without any scientific anticipation of the consequences of the policies (2007). This forces the question of what was the rationale of the SORN policies. In the next section, we discuss the theory and concept for the policies.

\subsection{Theory and Concept}

Although some studies suggest that the SORN policies are solely driven by the political attempts to make the public feel safer, reduction in the actual sex crimes after this policy is not known (Meloy, Saleh, \& Woff, 2007; Sample, Evans, \& Anderson, 2011). The original purpose of Sex Offender Registration and Notification Act of 2006 is as follows:

"In order to protect the public from sex offenders and offenders against children, and in response to the vicious attacks by violent predators against the victims listed below, Congress in this Act establishes a comprehensive national system for the registration of those offenders: ... (Listed 17 sexually assaulted victims including Jacob Wetterling and Megan Nicole Kanka)."

In theory, based on this purpose of the act postulated, registration and notification policy systems should contribute 'to protect public from sex offenders and offenders against children.' The assumption behind the theory is that when people know their surroundings, they have the higher chances of being victimized. There was no evidence that the implementation of the SORN policies would create public safety, however (Freeman \& Sandler, 2010). Knowing one's surroundings does not always keep him or her safe. The notion of 'more information, more protection' is false according to the prior studies on fear of crime (Tewksbury, Jennings, \& Zgoba, 2012; Ackerman \& Sacks, 2012; Sample, Evans, \& Anderson, 2011; Prescott \& Rockoff, 2011). The researchers studying fear of crime conclude that the levels of acknowledgment about the crimes and fear are not associated with actual victimization occurring at an individual level (Smith \& Hill, 1991). These results indicate that knowing that a registered sex offender lives in a neighborhood is hardly able to prevent victimization of the person with said knowledge.

Considering the SORN policies, the policymakers took the easiest path for satisfying the public with the least risky policies. The registration and notification policies do not actually protect the public. This policy only allows offender information available to the public. Technically, a piece of information cannot protect the public from actual sex offenders. These policies basically ask the public to protect themselves with the information without promising any security. Thus, the shallow general assumption of 'knowing better allows better protection' was simply the major presumption of the act that was empowered by public panic (Meloy, Saleh, \& Woff, 2007).

As a result, SORN policy did not show a significant deterrent effect on sex offenders. Regarding general and specific deterrent effects, most evaluations suggested that there are only a little evidence to support the initial purpose of the act - little impact on 'protecting' the public from sex offenders (Tewksbury, Jennings, \& Zgoba, 2012; Ackerman \& Sacks, 2012; Sample, Evans, \& Anderson, 2011; Prescott \& Rockoff, 2011). Then why are these policies are still active?

This theoretical hustling process with the SORN policies is a result of 'good intention with reckless ideas' (Zgoba, Veysey, \& Dalessandro, 2010). The main reason for this theoretical challenge is that the policies stemmed from the public desire to be 'tough on sex offenders.' The initial concept of the SORN policies was based on the public's right to know the danger around their neighborhoods. This theory did not have to be directly related to crime prevention, but it might be able to prevent some incidents. However, this was not the case. From 'good intention' to 'good ideas,' the SORN needed more theoretical challenges when the policymakers discussed the possible theoretical framework.

\subsection{Implementation}

Even though unsound theories were developed for SORNA, there are many laws in the book that are theoretically unsound but still in a continuum. Then, the question is, even if the theoretical framework of SORNA is right, what is the 
chance of success of implementing SORNA with fidelity across the nation? Surprisingly, there are only a few studies considering difficulties of as well as evaluating the SORN implementation (Meloy, Curtis, \& Boatwright, 2013; Ackerman, Sacks, \& Osier, 2013). According to research conducted by Harries and Lobanov-Rostovsky in 2009, several states presented inconsistencies with federal-level mandatory guidelines, in particular, ones related to the classification of sex offenders and juvenile inclusion.

The study identified implementation limitations - legal, operational, financial, and practical barriers that make states difficult to implement SORNA provisions fully. The reason for all difficulties for the states to fully implement SORN was because of the complexity of the law itself. The research found total of 8 components of compliance failure (The Council State Governments, 2010), yet the reason that most states failed to comply with this law was mainly due to four statutory requirements: classification of sex offenders (Tier type I, II, III), registration information and frequency for update, new rules for juvenile registry, and retroactive registration. Each state takes this issue differently; therefore, variations exist throughout the nation even though the same guideline is provided. The operational barrier is also a technical issue with the information readiness. For example, the United States Department of Justice (2008) reported that while $85-88 \%$ of 52 public registries contained information regarding offender's home address as well as picture, only less than $19 \%$ contained information regarding electronic notification upon request of changes in offender's status, address of school affiliation, and vehicle information.

Unlike the initial anticipation, there were also financial challenges; human resources are getting expensive while more offenders are being considered for the registration and notification. Even though the costs of operating the SORN programs are not as much as operating a prison, the operation needs sufficient resources. While the registration and notification started with strong support from the public and politics, many jurisdictions have difficulties keeping their operational expenses with the 'net widening' of the range of offenders. This is partial because the SORN programs were planned under budget with the presumption that the programs are using already existing information with existing personnel for the process.

Finally, some states have specific limitations on 'widening' issues, which are considered as a practical barrier to the implementation. Because of the federalized government system in the United States, a unified implementation of any policy throughout the nation is barely possible. Moreover, even though the SORN Act has been federally decided, details of the registration and notification practices are provided as a guideline but are not mandatory. This guideline allows much discretion by each state.

In terms of how well the policies have been executed, not many studies demonstrated such issues except result-driven researches. Nonetheless, the result-driven studies that evaluate the effectiveness of the SORN policy on deterrence of sex offenders have concluded that these policies are ineffective (Tewsbury, Jennings, \& Zgoba, 2012; Ackerman \& Sacks, 2012; Prescott \& Rockoff, 2011; Letourneau, Bandyopadhyay, Armstrong, \& Sinha, 2010). At this point, the scarce evidence is available on how well the policies are being executed by the SORN programs.

\subsection{Self-Reflection}

Fortunately, a number of researchers are attempting to evaluate the SORN policies and programs mainly regarding two aspects, legal issues and effectiveness of the act and its practice. However, the evaluations have not been promising thus far. These studies have agreed over the aggregative conclusions: The Sex Offender Registration and Notification policies are not effective in deterring the offenders and have a number of serious constitutional challenges (Scott \& Gerbasi, 2003; Yung, 2009; Harris \& Lobanov-Rostovsky, 2010). Yet, no political action is taken with consideration to these results.

Moreover, another direction of measuring the effectiveness of SORN should be considered. This direction should go beyond only measuring the deterrent effect on the offenders. Since SORNA is not risk-based, many low-risk offenders could be erroneously classified as high risk while truly dangerous offender may be determined as low-risk to receive fewer restrictions placed upon them. Moreover, the crime that offender is charged may not reflect the seriousness of the underlying offense. The root problem of the effectiveness measure is a theoretical weakness - theoretically, there is no other way the registration and notification can protect people from crimes. For instance, SORN gives "false sense of security" to the public since not all offenders are included on every website, sex offenders may often move, and not all sex offender comply with their registration requirements.

Furthermore, some studies suggest that the public is not very aware of the sex offender registry or the notification policies (Kernsmith, Comartin, Craun, \& Kernsmith, 2009; Anderson \& Sample, 2008). This fact also raises the question whether or not the public awareness should be considered when looking at the level of policy execution.

According to the analysis, applying the framework of four types of failures in criminal justice reform, the Sex Offender Registration and Notification policies are applicable to all four types of failure so far. However, there is one more 
dimension of the SORN policies that needs to be considered: constitutional issues with the policies. Therefore, the legal issues related to the SORN operation are discussed in the next section.

\section{Legal Issues with Sex Offender Registration and Notification Policies}

With rapid policy implementation of the Sex Offender Registration and Notification Act, there are legal concerns related to the constitutional rights of the offenders who are openly registered as sex offenders.

\subsection{Ex Post Facto}

The legal term 'Ex Post Facto' means "after the action" in Latin, which is noted in Article I of the Constitution. This clause protects an individual from being labeled as criminal under the new law due to previous crimes committed even before the law. Therefore, SORN should not be applied to sex offenders who committed the sex crime before the enactment of SORN.

\subsection{Fifth and Eighth Amendments}

The Fifth Amendment prohibits double jeopardy in criminal justice procedures. Yet, SORNA generates a feeling among sex offenders that they are being punished both inside and outside of prison. After spending years in prison for a sex offense, the offenders are put on the registry as a means to alert the public. This exposure of self-identity of sex offenders not only takes away their chances for community reintegration but also forms a "double jeopardy" as a secondary punishment. This clearly violates the Fifth Amendment.

In addition, this notion of secondary punishment or the SORN itself violates the Eighth Amendment in terms of cruel and unusual punishment. Although the concepts of 'cruel' and 'unusual' may be arbitrary, some sex offenders might consider this aftermath registration and notification as cruel and unusual.

Some studies also identified several possible collateral damages of sex offender registries; societal difficulties of family members and depression among the individuals listed in the registry (Levenson \& Tewksbury, 2009; Tewksbury \& Levenson, 2009; Jeglic, Mercado, \& Levenson, 2012). Thus, these factors can be interpreted as even crueler and unusual to some sex offenders.

\subsection{Fourteenth Amendment (Due Process and Equal Protection)}

The Fourteenth Amendment protects an individual's right to due process in that states cannot violate the individual's life, liberty, or property without due process of law. The SORN policies are criticized due to a violation of two types of due process - substantive and procedural.

The general idea of the substantive due process is that the rights and liberty of citizens are protected under any circumstances except when there is a proper justification. Also, under this proper justification, there must be a specification on which right may be compromised. Opponents of the registration and notification policies challenge that the government's justifications are not appropriate and that too many rights - privacy, liberty, and anonymity - have been compromised. Unlike this substantive due process, the procedural due process involves certain negotiations between the individual and the government, looking for the best interests of both (Chemerinsky, 1998). However, the SORN policies do not provide a chance for the registered individuals to appeal their interests to the government. This is a violation of procedural due process.

Thus far, the Sex Offender Registration and Notification policies in the United States were evaluated, and its related issues were discussed. Now the question turns to discussing some similarities and differences among countries in policies regarding sex offenders.

\section{Sex Offender Registration and Notification Policies in Other Countries}

\subsection{United Kingdom}

As a part of the Sexual Offences Act 2003, the United Kingdom has a Violent and Sex Offender Register (ViSOR) database of registered violent and sex offenders. These offenders are those who are incarcerated more than a year for violent or sex offenses. There are three sources of registration: the Police, National Probation Service, and HM Prison Service personnel. The National Policing Improvement Agency of the Home Office manages the national database. The policy was significantly influenced by the United States' policies (Lieb, Kemshall, \& Thomas, 2011).

\subsection{Canada}

Even though Canada developed the public consensus similar to the United States due to high-profile sex offenses since the 1980s, the policymakers moved more slowly and cautiously compared to the United States (Petrunik, 2003). The Province of Ontario operated a separate sex offender registry along with the federal database since 2001. However, there is a discrepancy between the federal and the province regarding whether the threat of the offender matters. This difference makes the Ontario registry much harsher than the other areas. Therefore, in 2004, Canada enacted the 
National Sex Offender Registry (NSOR) as a part of the Sex Offender Information Registration (SOIR) Act. Yet, the public has no access to the registry.

\subsection{Australia}

The Australian government established the internet database called the Australian National Child Offender Register (ANCOR). The ANCOR is used only by authorized personnel to monitor registered child sex offenders. The mandatory monitoring is eight years plus fifteen years or life. For juvenile offenders, the monitoring period is seven years and six months.

\subsection{South Korea}

The process of legislation of the Sex Offender Registration and Notification policies in South Korea is similar to what is found in the United States. After several high-profile crimes against children during the late 1990s, public concerns started to emerge. As transferring the United States' policies, in 2004 and 2006, the Sex Offender Registration and Notification policy was introduced as a newer part of the Protection of Children and Youth's Sex Act (PCYSA) of 2000. Throughout the years, these sex offender policies had been revised several times by the Supreme Court. Even though the policies are relatively new, scholars started to perceive ineffectiveness of the policies (Lee, 2011).

In an attempt to define a new act, the Special Act for Sexual Violent Offenders (SASVO) was introduced in 2008. The PCYSA is operated by the Ministry of Women and Family while the SASVO is managed by the Ministry of Justice. Not only some researchers suggest that these two ministrations are unnecessary, but also similar concerns regarding the policies of the United States are emerging: 1) violation of equity of law (other dangerous crime offenders are not notified), 2) violation of human rights, and 3) ineffectiveness of the policies (Lee, 2011; Shin \& Lee, 2005).

\section{Future of Sex Offender Registration and Notification Policies}

Thus far, we have explored how successful the Sex Offender Registration and Notification policies are in the United States. Even though the current assessment concludes that the policies are more on a failure track than on a successful track in terms of accomplishment of the goals, these policies are being stretched further - application to other offenders, policy transferring overseas, and attempts to revise the current policies.

\subsection{Net-Widening}

Even though the policies are at the federal level, there are many inconsistencies among states in terms of practice. One of the issues is an inclusion of juvenile sex offenders into the sex offender registry. Prior to SORNA, many jurisdictions in the United States chose to require particular juveniles who are adjudicated delinquent of sex offenses to register as sex offenders. However, SORNA's minimum standards currently do require registration for certain juvenile adjudicated delinquent of serious sex offenses. Consequently, some jurisdictions do not register any juveniles at all; some limit offender's ages to be registered; and some others limit the duration or public availability of registration information (Gonzales, 2007). Because juvenile registration requirements vary across many jurisdictions, it signifies the problem. Due to this problematic SORN application, there are some movements that we should build other offender registries (Craun, Kernsmith, \& Butler, 2011). These attempts to apply the registration and notification policies are called 'widening the net' (Harris, Lobanov-Rostovsky, \& Levenson, 2010).

\subsection{Overseas}

A number of countries are currently operating and implementing a sex offender registry and/or notification policies. Still, similar problems to what the United States criminal justice system is experiencing are occurring in these countries - constitutional and effectiveness issues. Without thorough examination and anticipation of the policies and the results, sole transfer of the policies to another country will not prevent the public from sex offenders.

\section{Better SORN in the United States}

In spite of significant advances in knowledge and practice among criminal justice agencies, the practitioners are still struggling how to respond to certain issues regarding crimes. What should be the future of the Sex Offender Registration and Notification policies in the United States? About 234,000 convicted sex offenders are under the care, custody, or control of corrections agencies on an average day. This statistic denotes how much it is important to come up with effective policy or programs to reduce sex offenses. It becomes, even more, clear that careful implementation of SORNA can resolve many constitutional issues that were aforementioned. We now know where the problem of SORN originates - a lack of theoretical structure. A good policy reform not only requires a good intention but also requires a sound theoretical framework. A strong theoretical framework allows criminal justice practitioners to identify the underlying mechanisms of crime occurrences and to find potential prevention measures. Even if the theory is sound, however, we are still dubious if this law can be implemented with fidelity. Because the initial goal of SORNA was to prevent the public from victimization of a sex offense, many research studies incorporated strain theory to discuss its 
efficacy in reducing recidivism rates of sex offenders. When these studies found that there is no significant effect on sex offenders' future crimes (Ackerman, \& Sacks, 2012; Appelbaum, 2008; Letourneau, Levenson, Bandyopadhyay, Armstrong, \& Sinha, 2010; Prescott, \& Rockoff, 2011), researchers are now trying to shift the goal of SORN from prevention to public perception of safety.

There were many factors to consider and states had difficulties or issues complying with SORNA requirements. This study was thus meaningful to analyze SORNA with four important typologies that are necessary for determining whether the law can be successful or unsuccessful. In this aspect, more researchers should play an important role in informing future SORN practices. In turn, more efforts from policymakers are needed in analyzing the most recent research findings and carefully plan out what next steps for SORNA reform should be.

\section{References}

Ackerman, A. R., \& Sacks, M. (2012). Can general strain theory be used to explain recidivism among registered sex offenders? Journal of Criminal Justice, 40(3), 187-193.

Ackerman, A. R., Harris, A. J., Levenson, J. S., \& Zgoba, K. (2011). Who are the people in your neighborhood? A descriptive analysis of individuals on public sex offender registries. International Journal of Law and Psychiatry, 34(3), 149-159.

Ackerman, A. R., Sacks, M., \& Osier, L. N. (2013). The experiences of registered sex offenders with internet offender registries in three states. Journal of Offender Rehabilitation, 52(1), 29-45.

Appelbaum, P. S. (2008). Sex offenders in the community: Are current approaches counterproductive? Psychiatric Services, 59(4), 352-354.

Batastini, A. B., Hunt, E., Present-Koller, J., \& DeMatteo, D. (2011). Federal standards for community registration of juvenile sex offenders: An evaluation of risk prediction and future implications. Psychology, Public Policy, and Law, 17(3), 451-474.

Beck, V. S., \& Travis, L. F. (2004). Sex offender notification and fear of victimization. Journal of Criminal Justice, 32(5), 455-463.

Berman, G., \& Fox, A. (2010). Trial and Error in Criminal Justice Reform: Learning from Failure.

Caputo, A. A., \& Brodsky, S. L. (2004). Citizen coping with community notification of released sex offenders. Behavioral Sciences and the Law, 22(2), 239-252.

Carpenter, C. L., \& Beverlin, A. E. (2012). The evolution of unconstitutionality in sex offender registration laws. Hastings Law Journal, 63(4), 1071-1133.

Chemerinsky, E. (1998). Substantive due process. Touro Law Review, 15,1501-1534.

Craun, S. W., Kernsmith, P. D., \& Butler, N. K. (2011). "Anything that can be a danger to the public": Desire to extend registries beyond sex offenses. Criminal Justice Policy Review, 22(3), 375-391.

Freeman, N. J. (2012). The public safety impact of community notification laws: Rearrest of convicted sex offenders. Crime and Delinquency, 58(4), 539-564.

Freeman, N. J., \& Sandler, J. C. (2010). The adam walsh act: A false sense of security or an effective public policy initiative? Criminal Justice Policy Review, 21(1), 31-49.

Gonzales, A. R. (2007). The national guidelines for sex offender registration and notification; notice (Part V, Department of Justice). Federal Register, 72(103), 30209-30234.

Harris, A. J., \& Lobanov-Rostovsky, C. (2010). Implementing the adam walsh act's sex offender registration and notification provisions: A survey of the states. Criminal Justice Policy Review, 21(2), 202-222.

Harris, A. J., Lobanov-Rostovsky, C., \& Levenson, J. S. (2010). Widening the Net The Effects of Transitioning to the Adam Walsh Act's Federally Mandated Sex Offender Classification System. Criminal justice and behavior, 37(5), 503-519.

Hughes, L. A., \& Kadleck, C. (2008). Sex offender community notification and community stratification. Justice Quarterly, 25(3), 469-495.

Jeglic, E. L., Mercado, C. C., \& Levenson, J. S. (2012). The prevalence and correlates of depression and hopelessness among sex offenders subject to community notification and residence restriction legislation. American Journal of Criminal Justice, 37(1), 46-59.

Kernsmith, P. D., Comartin, E., Craun, S. W., \& Kernsmith, R. M. (2009). The relationship between sex offender 
registry utilization and awareness. Sexual Abuse: Journal of Research and Treatment, 21(2), 181-193.

Lee, Kyung-Jae (2011). Problems and Solution of Sex Offender Registration and Notification Policies, Kangwon Law School, 33, 361-405.

Letourneau, E. J., Levenson, J. S., Bandyopadhyay, D., Armstrong, K. S., \& Sinha, D. (2010). Effects of south carolina's sex offender registration and notification policy on deterrence of adult sex crimes. Criminal Justice and Behavior, $37(5), 537-552$.

Letourneau, E. J., Levenson, J. S., Bandyopadhyay, D., Sinha, D., \& Armstrong, K. S. (2010). Effects of south carolina's sex offender registration and notification policy on adult recidivism. Criminal Justice Policy Review, 21(4), 435-458.

Levenson, J., \& Tewksbury, R. (2009). Collateral damage: Family members of registered sex offenders. American Journal of Criminal Justice, 34(1-2), 54-68.

Lieb, R., Kemshall, H., \& Thomas, T. (2011). Post-release controls for sex offenders in the U.S. and UK. International Journal of Law and Psychiatry, 34(3), 226-232.

Lipsey, M. W. (1992). Juvenile Delinquency Treatment: A Meta-Analytic Inquiry into the Variability of Effects. In Meta-Analysis for Explanation: A Casebook, edited by T.D. Cook, H. Cooper, D.S. Cordray, H. Hartmann, L.V. Hedges, R.J. Light, T. A. Louis, and F. Mosteller. New York: Russell Sage Foundation.

Locke, C., \& Chamberlin, B. F. (2007). Safe from sex offenders? legislating internet publication of sex offender registries. Urban Lawyer, 39(1), 1-18.

Maddan, S., Miller, J. M., Walker, J. T., \& Marshall, I. H. (2011). Utilizing criminal history information to explore the effect of community notification on sex offender recidivism. Justice Quarterly, 28(2), 303-324.

Meloy, M. L., Saleh, Y., \& Wolff, N. (2007). Sex offender laws in america: Can panic-driven legislation ever create safer societies? Criminal Justice Studies, 20(4), 423-443.

Meloy, M., Curtis, K., \& Boatwright, J. (2013). The sponsors of sex offender bills speak up: Policy makers' perceptions of sex offenders, sex crimes, and sex offender legislation. Criminal Justice and Behavior, 40(4), 438-452.

Petrunik, M. (2003). The hare and the tortoise: Dangerousness and sex offender policy in the United States and Canada. Canadian Journal of Criminology and Criminal Justice, 45(1), 43-72.

Prescott, J. J., \& Rockoff, J. E. (2011). Do sex offender registration and notification laws affect criminal behavior? Journal of Law and Economics, 54(1), 161-206.

Protection, A. W. C. Safety Act of 2006.(2006). In 109th Congress, 2nd Session, HR (Vol. 4472).

Sample, L. L., Evans, M. K., \& Anderson, A. L. (2011). Sex offender community notification laws: Are their effects symbolic or instrumental in nature? Criminal Justice Policy Review, 22(1), 27-49.

Scott, C. L., \& Gerbasi, J. B. (2003). Sex offender registration and community notification challenges: The supreme court continues its trend. Journal of the American Academy of Psychiatry and the Law, 31(4), 494-501.

Shin, J., \& Lee, Y. (2005). Korean version of the notification policy on sexual offenders: Did it enhance public awareness of sexual crimes against minors? International Journal of Offender Therapy and Comparative Criminology, 49(4), 376-391.

Smith, L. N. \& Hill, G. D. (1991) Victimization and Fear of Crime. Criminal Justice and Behavior, 18, $217-39$.

Southwick, M., \& Rubin, S. (2004). Who are the people in your neighborhood? the effects of community notification on the community. Journal of Police and Criminal Psychology, 19(2), 1-14.

Stolzenberg, L., \& D'alessio, S. J. (1997). "Three strikes and you're out": The impact of California's new mandatory sentencing law on serious crime rates. Crime \& Delinquency, 43(4), 457-469.

Tewksbury, R., \& Jennings, W. G. (2010). Assessing the impact of sex offender registration and community notification on sex-offending trajectories. Criminal Justice and Behavior, 37(5), 570-582.

Tewksbury, R., \& Levenson, J. (2009). Stress experiences of family members of registered sex offenders. Behavioral Sciences and the Law, 27(4), 611-626.

Tewksbury, R., Jennings, W. G., \& Zgoba, K. M. (2012). A longitudinal examination of sex offender recidivism prior to and following the implementation of SORN. Behavioral Sciences and the Law, 30(3), 308-328.

Visgaitis, R. L. (2011). Retroactive application of the sex offender registration and notification act: A modern encroachment on judicial power. Columbia Journal of Law and Social Problems, 45(2), 273-302. 
Yung, C. R. (2009). One of these laws is not like the others: Why the federal sex offender registration and notification act raises new constitutional questions. Harvard Journal on Legislation, 46(2), 369-424.

Zevitz, R. G., Crim, D., \& Farkas, M. A. (2000). Sex offender community notification: Managing high risk criminals or exacting further vengeance? Behavioral Sciences and the Law, 18(2-3), 375-391.

Zgoba, K., Veysey, B. M., \& Dalessandro, M. (2010). An analysis of the effectiveness of community notification and registration: Do the best intentions predict the best practices? Justice Quarterly, 27(5), 667-691.

Zimring, F. E. (1996). Populism, Democratic Government, and the Decline of Expert Authority: Some Reflections on Three Strikes in California. Pac. Lj, 28, 243.

\section{(c)) EY}

This work is licensed under a Creative Commons Attribution 3.0 License. 